vchytelya [Implementation of ideas of humane pedagogics of Galicia (end of the XIX - the beginning of the twentieth century) in modern university teacher training]. Pedagogics and psychology of vocational education. No.2, pp.172-177. [in Ukrainian].

3. Galushchinsky, M. (1927). Pozashkilna osvita : (narodyny, - osvitni ustanovy, - orhanizatsiyni formy, meta) [Out-of-school education: (peoples, - educational institutions, - organizational forms, - purpose)]. Lviv, $47 \mathrm{p}$. [in Ukrainian].

4. Zavgorodnya, T.K. (2007). Teoriya i praktyka navchannya $v$ Halychyni (1919 - 1939 roky): monohrafiya. [The theory and practice of teaching in Galicia (1919-1939): monograph]. 392 p. [in Ukrainian].

5. Lyubar, O. O., Stelmakhovich, M.G. \& Fedorenko, D.T. (2006). Istoriya ukrayinskoyi shkoly i pedahohiky: navch. posib. [History of Ukrainian School and Pedagogy: Teach. Manual]. Kyiv, 447 p. [in Ukrainian].

6. Potapiuk, L. (2015). Ideolohichni ta sotsialnopedahohichni prychyny vynyknennya i rozvytku kulturnoprosvitnytskykh hromad na Zakhidniy Ukrayini (druha polovyna XIX - pochatok XX st.) [Ideological and sociopedagogical reasons for the emergence and development of cultural and educational communities in Western Ukraine (second half of the XIX - early XX centuries)]. Origins of pedagogical skill. Issue 15, pp. 252-257. [in Ukrainian].

7. Patushnyak, F. \& Petrovich, I. (2011). Ridna literatura [Native literature]. Enemies of the Ossey bourgeoisie. (Ed.).I. Petrovtsy, pp. 461-462. [in Ukrainian].

8. Smal-Stotsk, S. (1896). Polityka realna [Politics is real]. Bukovina, p. 85. [in Ukrainian].

9. Franko, I. (1976). Teoriya i rozviy istoriyi literatury [Theory and Literacy History]. Vol. 40. Kyiv, 440 p. [in Ukrainian].

10. Franco, I. (1976). Tvory: v $50 t$. [Works: 50 t.]. Vol. 19. Kyiv, 220 p. [in Ukrainian].

11. Franko, I. (1984). Ukrainska almanakhova literatura [Ukrainian Almanac Literature]. Works in: 50 vol; Vol. 27. Kyiv. [in Ukrainian].

12. Die Zeit. (1901). No. 356, pp. 18-25. [in Deutch].

Стаття надійшла до редакції 15.03.2019

УДК 796.011.3:373.3

DOI:

Олена Сакалюк, кандидат педагогічних наук, старший викладач кафедри початкової освіти Київського університету імені Бориса Грінченка

\title{
ФОРМУВАННЯ ЗДОРОВ'ЯЗБЕРЕЖУВАЛЬНОЇ КОМПЕТЕНТНОСТІ УЧНІВ ПОЧАТКОВИХ КЛАСІВ ЗАСОБАМИ КІНЕЗІОЛОГІЧНИХ ФІЗКУЛЬТХВИЛИНОК
}

У статті розглядається проблема важливості формування здоров 'язбережувальної компетентності учнів початкових класів засобами кінезіологічних фізкультхвилинок; виокремлюється класифікація здоров'язбережувальних технологій; висвітлюються сучасні підходи до інтерпретації поняття “здоров'язбережувальна компетентність” в умовах реформування системи освіти України; пропонується комплекс кінезіологічних фізкультхвилинок для формування здоров'язбережувальної компетентності молодиих школярів.

Ключові слова: здоров'язбережувальна компетентність; здоров'язбережувальні технології; кінезіологічні вправи.

Jim. 10.

Olena Sakalyuk, Ph.D.(Pedagogy), Senior Lecturer of the Primary Education Department Borys Hrinchenko Kyiv University

\section{FORMATION OF HEALTHCARE-SAVING COMPETENCE OF PRIMARY SCHOOL STUDENTS BY THE MEANS OF KINESIOLOGICAL EXERCISE MINUTES}

The article deals with the problem of the importance of the formation of health and preserving competence of primary school students by means of kinesiological exercise minutes; singles out the classification of healthcaresaving technologies; highlights the modern approaches to the interpretation of the concept "health-saving competence" in the context of reforming the education system of Ukraine; offers a complex of kinesiological exercise minutes for the formation of health-saving competence of junior pupils.

The article states that one of the means of solving the above tasks is the use of health-saving technologies, without which the educational process of a modern educational institution became impossible. It is also very important that each technology has a health-improving orientation, and used in the complex health protective activities would form a sustainable motivation for younger students in a healthy way of life. The process of formation of healthcare-saving competence in primary school students can not be avoided without the use of kinesiological exercise minutes. With the help of kinesiology, health improves, basic mental processes are optimized (memory, 


\section{ФОРМУВАННЯЗДОРОВ’ЯЗБЕРЕЖУВАЛЬНОӤ КОМПЕТЕНТНОСТІ УЧНІВ ПОЧАТКОВИХ КЛАСІВ ЗАСОБАМИ КІНЕЗІОЛОГІЧНИХ ФІЗКУЛЬТХВИЛИНОК}

attention, thinking, speech, hearing, imagination, perception), mental working capacity and psycho-emotional state of students increases.

Keywords: health-preserving competence; health-saving technologies; kinesiological exercises.

П остановка проблеми. Одним із основних завдань сучасної школи є створення освітнього середовища для розвитку здорової дитини, формування в учнів початкових класів свідомого ставлення до свого життя і здоров'я, оволодіння навичками безпечного життя і здорової поведінки.

Нажаль, за даними сучасних досліджень, майже 90\% українських школярів мають відхилення у здоров' $і$, понад 50\% - незадовільну фізичну підготовку, близько 60\% мають низький рівень фізичного розвитку. Екологічний, соціальний, економічний стани, які склалися в нашій державі на цей час, не дають змоги покращити показники захворюваності. Невтішною також є і система шкільного фізичного виховання, котра, у першу чергу, повинна вирішити задачі зміцнення та покращення здоров'я дітей, різнобічного фізичного розвитку, загартовування учнів [3].

Відповідно до нормативно-правових документів - Конституції України, Законів України "Про освіту”, “Про позашкільну освіту”, Національної стратегії розвитку освіти в Україні на 2012 - 2021 роки одним із пріоритетів державної освітньої політики є створення оптимальних умов для формування, збереження та зміцнення здоров'я учнівської молоді, розвитку фізично здорової та духовно багатої особистості.

Доведено, що в розвиненомусуспільстві рівень здоров'я значною мірою пов'язаний із рівнем освіти. Чим вищий освітній рівень певного соціального середовища, тим кращі, як правило, у ньому узагальнені показники здоров'я. Отже завдання збереження й зміцнення здоров'я потрібно розв' язувати, насамперед, педагогічними засобами, при цьому, освіта в аспекті здоров'язбереження розуміється комплексно: і як надання інформації, і як навчання методів, прийомів і навичок здорового способу життя, і як виховання в дусі безумовного пріоритету цінностей індивідуального і громадського здоров'я в усіх його проявах, сферах, рівнях [2, 94].

Проблема здоров'я молодших школярів розглядається в дослідженнях таких сучасних соціологів, медиків, педагогів, психологів, методистів як: Т. Андрющенко, Н. Бібік, Є. Вайнер, С. Дудко, О. Ващенко, С. Кондратюк, В. Оржеховська, О. Савченко, М. Удовенко.

Основні принципи організації оздоровчої освіти та виховання учнів висвітлено упрацях М. Гриньової, С. Кириленка, Л. Заплатнікова, Л. Пономарьової,
Б. Шияна. Застосування здоров'язберігаючих технологій у сучасній українській школі проаналізованоупрацях В. Лозинського, Л. Антонової, М. Смірнова, В. Циганова, Є. Юніної.

Більшість досліджень цієї проблеми сфокусовані на вивченні особливостей формування та розвитку здоров'язберігаючих компетентностей у школярів, тому метою нашої статті є: обгрунтувати та довести необхідність формування здоров' язбережувальної компетентності учнів початкових класів за допомогою кінезіологічних фізкультхвилинок; визначити технології формування здоров'язбережувальної компетентності молодших школярів.

Виклад основного матеріалу. Згідно Державного стандарту базової і повної загальної середньої освіти здоров'язбережувальна компетентність - здатність учня застосовувати в умовах конкретної ситуації сукупність здоров' язбережувальних компетенцій, дбайливо ставитися до власного здоров'я та здоров'я інших людей [7].

На думку Н.В. Тамарської суть поняття “здоров'язбережувальна компетентність” проявляється у проведенні профілактичних заходів i застосуванні здоров'язбережувальних технологій людьми, що знають закономірності процесу здоров'язбереження $[4,11]$.

Т.Г. Шаповалова визначає здоров'язбережувальну компетентність як інтегральну динамічну рису особистості, що проявляється в здатності організувати здоровий спосіб життя й регулювати діяльність, спрямовану на збереження здоров'я; адекватно оцінювати свою поведінку, а також учинки й погляди оточуючих; зберігати та реалізовувати власні здоров'язберігаючі позиції в різних, зокрема, несприятливих умовах. Виходячи 3 особисто засвоєних моральних норм та принципів, а не за рахунок зовнішніх сил; протистояти негативному тиску, протидіяти впливам, що суперечать внутрішнім установкам, поглядам i переконанням, активно їx перетворювати, самостійно приймати моральні рішення $[10,196]$.

На думку О. Ващенко “здоров’ язбережувальна компетентність” - це комплекс знань, умінь, ставлень та цінностей, які спрямовані на збереження й укріплення здоров'я - свого та оточуючих, на уроках та в позаурочній діяльності $[1,4]$.

Одним із засобів вирішення окреслених завдань $\epsilon$ застосування здоров'язбережувальних 


\section{ФОРМУВАННЯ ЗДОРОВ'ЯЗБЕРЕЖУВАЛЬНОЇ КОМПЕТЕНТНОСТІ УЧНІВ ПОЧАТКОВИХ КЛАСІВ ЗАСОБАМИ КІНЕЗІОЛОГІЧНИ ФІЗКУЛЬТХВИЛИНОК}

технологій, без яких став неможливим освітній процес сучасного навчального закладу. Аналіз наукових публікацій з даної проблеми засвідчив наявність різноманітних підходів до визначення поняття “здоров'язбережувальні технології”.

На думку В. Єфімової, “поняття “здоров'язбережувальні технологіі” потрібно розглядати “як частину педагогічної науки, яка вивчає і розробляє цілі, зміст і методи навчання здорового способу життя, спрямована на вирішення питань здоров'язбереження в системі освіти; як спосіб організації, модель навчального процесу, що гарантує збереження здоров'я всіх суб'єктів навчального процесу; як інструментарій освітнього процесу, як системувказівок, які повинні забезпечити ефективність і результативність навчання разом із збереженням здоров'я учнів [6,59-60]”.

Аналізкласифікаційіснуючихздоров'язбережувальних технологій дає можливість виокремити такі типи:

- здоров'язберігаючі - технології, що створюють безпечні умови для перебування дитини в школі, ті, що вирішують завдання раціональної організації виховного процесу (врахування вікових, статевих, індивідуальних особливостей та гігієнічних норм), відповідності розумового та фізичного навантаження можливостям дитини;

- оздоровчі технології - спрямовані на вирішення завдань зміцнення фізичного здоров'я дітей (фізична підготовка, загартування, гімнастика, масаж, фітотерапія, аромотерапія, музична терапія).

- технології навчання здоров'ю - гігієнічне навчання, формування життєвих навичок, статеве виховання, профілактика травматизму;

- виховання культури здоров'я - виховання особистісних якостей, які сприяють збереженню і зміцненню здоров'я, формуванню уявлень про здоров'я, як цінність, посиленню мотивації на ведення здорового способу життя.

Реалізація здоров'збережувальних технологій передбачає:

- моніторинг рівня здоров'я школярів;

- організацію освітнього середовища в навчальних закладах за вимогами особистісноорієнтованого підходу;

- реалізацію діагностичних, корекційних і реабілітаційних заходів з учнями, залежно від групи здоров'я;

- створення комфортних умов перебування в школах для всіх дітей, в тому числі і з особливими потребами;

- вибір оптимальних технологій виховання i навчання з урахуванням віку, статі, індивідуальних особливостей розвитку дитини;
- оптимізацію соціально-гігієнічних умов життєдіяльності школярів і педагогів.

Таким чином, дуже важливо, щоб кожна 3 технологій мала оздоровчу спрямованість, а використана в комплексі здоров'язбережувальна діяльність, формувала б у молодших школярів стійку мотивацію на здоровий спосіб життя, повноцінний різнобічний розвиток [9].

Процес формування здоров'язбережувальної компетентності в учнів початкових класів не може обійтися без застосування кінезіологічних фізкульхвилинок. 3 допомогою засобів кінезіології зміцнюється здоров'я, оптимізуються основні психічні процеси (пам'ять, увагу, мислення, мова, слух, уяву, сприйняття), підвищується розумова працездатність, психоемоційний стан школярів.

Кінезіологія - це наука, що вивчає здатність людини через рухові вправи досягти розвитку розумових здібностей і повноцінного здоров'я.

Наукові дослідження, що проводились в психології і нейрофізіології виявили, що певні фізичні рухи впливають на розвиток інтелекту людини.

На підставі отриманих висновків виникла нова система - освітня кінезіологія, спрямована на координацію роботи правої і лівої півкулі й розвиток взаємодії рухів і психофізичних функцій.

Засновником освітньої кінезіології $\epsilon$ американський вчений Пол I. Деннісон, який все своє професійне життя присвятив сфері - освіти. Пол І. Деннисон доктор філософії та педагог за освітою. В 1960 році він почав дослідження 3 поліпшення читання і його зв'язок з поліпшенням мозку, яке надалі переросло в працю “Гімнастика для мозку”. Вчений розробив систему швидких, простих, специфічних рухів, що приносять користь кожному незалежно від його проблеми.

Враховуючи функціональну спеціалізацію півкуль (права - гуманітарна, ліва математична), а також роль спільної діяльності у здійсненні вищих психічних функцій, можна вважати, що порушення міжпівкульної передачі інформації спотворює пізнавальнудіяльність дітей початкової школи. В даний час зростає число дітей 3 мінімальними мозковими дисфункціями (близько 30\%), які проявляються порушенням мовлення, мислення, зміною якостей психіки. Доведено, що певну роль в їх виникненні грає порушення функціональної асиметрії кори великих півкуль головного мозку і міжпівкульної взаємодії. Проблема успішності в навчанні може бути вирішена, якщо в процесі життя використовується робота обох півкуль мозку [5].

Кінезіологічні фізкультхвилинки дають можливість задіяти ті ділянки мозку дітей, які 


\section{ФОРМУВАННЯ ЗДОРОВ'ЯЗБЕРЕЖУВАЛЬНОӤ КОМПЕТЕНТНОСТІ УЧНІВПОЧАТКОВИХ КЛАСІВ ЗАСОБАМИ КІНЕЗІОЛОГІЧНИХ ФІЗКУЛЬТХВИЛИНОК}

раніше не брали участі в навчанні. У ході занять у молодших школярів розвиваються міжпівкульні зв'язки, поліпшується пам'ять і концентрація уваги. Спостерігається значний прогрес у здібностях до навчання та вміння керувати своїми емоціями [8].

Кінезіологічні фізкультхвилинки ми визначаємо як вправи, які сприяють збудженню певних ділянок мозку і вмиканню механізму об'єднання думок і рухів. За допомогою спеціально підібраних кінезіологічних вправ організм координує роботу правої і лівої півкулі і розвиває взаємодію тіла та інтелекту. Кінезіологічні фізкультхвилинки полегшують всі види навчання і особливо ефективні для оптимізації інтелектуальних процесів і підвищення розумової працездатності учнів. Ці вправи покращують розумову діяльність, синхронізують роботу півкуль, сприяють запам'ятовуванню, підвищують стійкість уваги, допомагають відновленню мовленнєвих функцій, полегшують процеси читання і письма учнів початкових класів.

До комплексу кінезіологічних фізкультхвилинок входять:

- вправи на розвиток пам'яті, уваги, уяви, логіки у дітей, які мають недостатній рівень інтелектуальної готовності до навчання у школі (“Людина-павук”, “Кулак - ребро - долоня”, “Оладки”, "Вухо-ніс");

- вправи на розтягування, які нормалізують гіпертонус та гіпотонус ("Незвичайне крокування”, “Зірви яблука”, “Точки рівноваги”);

- дихальні вправи, які покращують ритміку організму, розвивають самоконтроль (“Хмара дихання");

- вправи для очей розвивають міжпівкульну взаємодію, підвищують енергію організму(“Окомандрівник”, “Ледачі вісімки для очей”);

- вправи для розвитку мислення та мовлення (“Точки землі”, “Кнопки мозку”, “Зігнута нога”);

- вправи для розвитку дрібної моторики (“Дзеркальне малювання”, “Слон”);

- вправи на зняття емоційного напруження, релаксація (“Свічка”, “Нирець”, “Енергетизатор”);

- вправи на подолання патологічних відхилень ("Перехресні кроки”, “Лобно-потиличний корекція");

- масаж.

Таким чином, ми дійшли до висновку, що здоров'язбережувальна компетентність - це багатогранний процес формування знань, удосконалення умінь та навичок, набуття досвіду збереження здоров'я, що проявляється у вмінні вести здоровий спосіб життя і прямо пропорційно підвищенню рухової активності та усвідомленому формуванні культури здоров'я молодших школярів.

У ході систематичних занять за кінезіологічними програмами в дитини зникають явища дислексії, розвиваються міжпівкульні зв' язки, поліпшується пам'ять і концентрація уваги. У зв'язку з поліпшенням інтегративної функції мозку в багатьох школярів спостерігається значний прогрес у здібностях до навчання та вміння керувати своїми емоціями. Кінезіологічні фізкультхвилинки покращують увагу і пам'ять, формують просторові уявлення учнів.

\section{ЛІТЕРАТУРА}

1. Ващенко О. М. Срмолова, В. М., Іванова Л.І. Фізкультурно-оздоровчі заходи в режимі навчального дня молодшого школяра : навч.метод. посіб. Кам'янець-Подільський, 2012. 192 с.

2. Гаркуша С. В. Формування готовності майбутніх фахівців фізичного виховання до використання здоров'язбережувальних технологій: теоретико-методичний аспект. Чернігів. 2014. 392 с. C.11.

3. ГрицайЮ. О. Використання здоров'язберігаючих технологій в навчальній діяльності школярів : навчальний посібник. Миколаїв, 2012.181 с.

4. Дошкільна освіта: словник-довідник: понад 1000 термінів, понять та назв / упор. К.Л. Крутій, О.О. Фунтікова. Запоріжжя, 2010. 324 с. Бібліогр.: С. 5-7. (“Словники”)

5. Дитяча кінезіологія. 2014. URL: hhttps:// www.slideshare.net/Natasha5717/ss-32554172.

6. Єфімова В. М. Здоров'язбережувальні технології у контексті педагогічних досліджень. Педагогіка, психологія та медико-біологічні проблеми фізичного виховання і спорту. 2010. №1. C. $59-60$.

7. Про затвердження “Державного стандарту базової і повної загальної середньої освіти” від 23 листопада 2011 p. №1392. URL: http:// zakon2.rada.gov.ua/laws/show/1392-2011$\% \mathrm{D} 0 \% \mathrm{BF}$.

8. Саєнко С. Кінезіологічні вправи. 2016. URL: http://logoped2.blogspot.com/2016/01/blogpost 41.html.

9. Формування основ здоров'язбережувальної компетентності у дітей дошкільного віку.2016. URL: http://rosynka-rivne.pp.ua/metodichna-stor$\mathrm{n} \mathrm{k} \mathrm{a} \mathrm{/} \mathrm{for} \mathrm{m} \mathrm{u} \mathrm{v} \mathrm{a} \mathrm{n} \mathrm{n} \mathrm{a} \mathrm{-} \mathrm{o} \mathrm{s} \mathrm{n} \mathrm{o} \mathrm{v} \mathrm{-} \mathrm{z} \mathrm{d} \mathrm{orov-}$ jazberezhuvalno.html.

10.Шаповалова Т.Г.Формуванняздоров'язбережувальної компетентності гуртківців у позашкільному навчальному закладі. Педагогічні науки: теорія, історія, інноваційні технології. 2012. № 2 (20). C. $191-199$. 


\section{REFERENCES}

1. Vashchenko, O. M., Yermolova, V. M. \& Ivanova, L. I. (2012). Fizkulturno-ozdorovchi zakhody $v$ rezhymi navchalnoho dnia molodshoho shkoliara : navch.-metod. posib. [Physical training and recreation activities in the mode of the school day of junior schoolchildren: teaching method. Manual]. Kamyanets-Podilsky, 192 p. [in Ukrainian].

2. Garkusha, S.V. (2014). Formuvannia hotovnosti maibutnikh fakhivtsiv fizychnoho vykhovannia do vykorystannia zdoroviazberezhuvalnykh tekhnolohii: teoretyko-metodychnyi aspekt [Formation of readiness of future specialists of physical education for the use of healthcare-saving technologies: theoretical and methodical aspect]. Chernigov, 392., p.11. [in Ukrainian].

3. Gritsay, Y. O. (2012). Vykorystannia zdoroviazberihaiuchykh tekhnolohii $v$ navchalnii diialnosti shkoliariv : navchalnyi posibnyk [The use of health-saving technologies in pupils' educational activity: a manual]. Mykolaiv, 181 p. [in Ukrainian].

4. Doshkilna osvita: slovnyk-dovidnyk: ponad 1000 terminiv, poniat ta nazv [Preschool education: dictionary-directory: over 1000 terms, concepts and names].(Ed.). Krutii, K.L., Funtikova. O.O. Zaporozhye, 2010. 324 p. Bibliogr .: pp. 5-7. ("Dictionaries") [in Ukrainian].

5. Dytiacha kineziolohiia (2014). [Children's kinesiology]. [Electronic resource]. Available at: // www.slideshare.net/Natasha5717/ss-32554172. [in Ukrainian].
6. Efimova, V.M. (2010). Zdoroviazberezhuvalni tekhnolohii u konteksti pedahohichnykh doslidzhen [Health-saving technologies in the context of pedagogical research]. Pedagogics, psychology and medical and biological problems of physical education and sports. No. 1,pp. 59-60. [in Ukrainian].

7. Pro zatverdzhennia "Derzhavnoho standartu bazovoi i povnoi zahalnoi serednoi osvity" vid 23 lystopada 2011 r. №1392. [On Approval of the State Standard for Basic and Complete Secondary Education of November 23, 2011 No. 1392]. Available at: http://zakon2.rada.gov.ua/laws/show/1392-2011$\% \mathrm{D} 0 \% \mathrm{BF}$ [in Ukrainian].

8. Sayenko, S. (2016). Kineziolohichni vpravy [Kinesiological exercises]. [Electronic resource]. Available at: http://logoped2.blogspot.com/2016/01/ blog-post_41.html. [in Ukrainian].

9. Formuvannia osnov zdoroviazberezhuvalnoi kompetentnosti u ditei doshkilnoho viku (2016). [Formation of the basis of health and preserving competence in children of preschool age]. [Electronic resource]. Available at: http: //rosynka-rivne.pp.ua/ metodichna-stor-nka/formuvannja-osnov-zdorovjazberezhuvalno.html. [in Ukrainian].

10. Shapovalova, T. G. (2012). Formuvannia zdoroviazberezhuvalnoi kompetentnosti hurtkivtsiv u pozashkilnomu navchalnomu zakladi [Formation of the health of preserving competence of circles in an out-of-school educational institution]. Pedagogical Sciences: Theory, History, Innovative Technologies. No. 2 (20), pp. 191-199. [in Ukrainian].

Стаття надійшла до редакції 12.03.2019

\section{G580

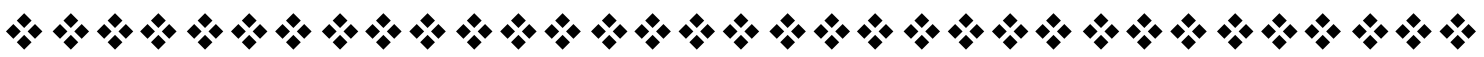

"Жаука - ие організовані знання, мудрість - ие організоване життя".

Іммануӥл Кант

німеиький ббілособб

"Ідіть впевнено у напрямку до мрї̈. Живіть тим життям, яке ви самі собі придумахи".

Тенрі Февід TTоро

американський письменник

"I малими ділами можна заслужити милість Божу. Ттиия радіє весні, а немовля - матері. Не забувайте того доброго, що вмієте, а чого не вмієте, того навчайтеся".

Володимир Мономах

державний діяч

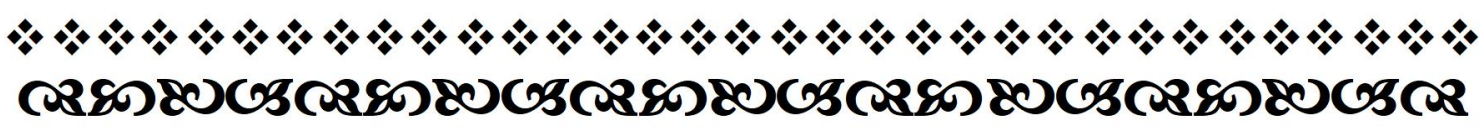

